\title{
PENGEMBANGAN DESAIN SISTEM KEAMANAN PANGAN MENGGUNAKAN HAZARD ANALYSIS CRITICAL CONTROL POINT (HACCP) PADA UKM PRODUSEN NUGGET IKAN
}

\author{
Food Safety System Design Development Using Hazard Analysis Critical Control Point \\ (HACCP) System on SME Fish Nugget Producer
}

\author{
Ajun Tri Setyoko dan Ellia Kristiningrum \\ Pusat Penelitian dan Pengembangan Standardisasi, Badan Standardisasi Nasional \\ Gedung I BPPT Lantai 12, Jalan M.H. Thamrin No. 8, Jakarta, Indonesia \\ e-mail: ajun_ts@bsn.go.id
}

Diterima: 13 September 2018, Direvisi: 16 November 2018, Disetujui: 19 November 2018

\begin{abstract}
Abstrak
UKM pangan sangat berkembang pesat di Bandung, salah satunya adalah produk nugget ikan. Produk olahan ikan ini merupakan pangan yang tinggi protein namun sangat rentan mengalami kerusakan dan berisiko tinggi. Oleh karena itu, untuk meningkatkan keamanan pangan pada proses pembuatan nugget ikan ini diperlukan penerapan HACCP. Tujuan penelitian ini adalah mengembangkan sistem HACCP pada salah satu UKM Nugget ikan di Bandung agar dapat menghasilkan produk yang aman untuk dikonsumsi. Tahapan proses produksi nugget ikan dimulai dari penerimaan bahan baku, pencucian bahan baku, penggilingan ikan, pencampuran, pembagian adonan, pelapisan dengan tepung pelapis, pembentukan adonan nugget, penggorengan setengah matang, nugget ikan, pendinginan dan pengemasan. Berdasarkan hasil identifikasi terdapat 4 proses yang menjadi titik kritis kontrol (CCP) yaitu penerimaan bahan baku, penggorengan, pendinginan dan pengemasan. Untuk meminimalkan potensi bahaya dibuat titik kendali kritis untuk masing-masing CCP dan sistem pemantauan dengan menetapkan tiga unsur untuk tiap CCP yaitu pembuatan prosedur, dokumentasi dan penetapan orang yang bertanggung jawab pada masing-masing proses yang menjadi CCP. Dengan penentuan titik kritis ini, UKM dapat membuat kontrol pada proses tersebut agar produk yang dihasilkan memiliki tingkat keamanan pangan yang baik. Penelitian ini juga memberikan rekomendasi pada UKM untuk memastikan penerapan HACCP dapat berjalan dengan baik. Beberapa rekomendasi terkait pada 5 aspek yang belum memenuhi persyaratan GMP yaitu aspek bangunan, keamanan air, pemeliharaan dan program sanitasi, bahan serta pengawasan.
\end{abstract}

Kata kunci: sistem keamanan pangan, HACCP, nugget ikan, UKM

\begin{abstract}
Food SMEs are very rapidly growing in Bandung, one of which is the fish nugget product. This processed fish product is a high-protein food but very susceptible to damage and high risk. Therefore, to improve food safety in the process of making fish nugget is needed the application of HACCP. The purpose of this study is to develop the HACCP system in one of the Nugget fish SMEs in Bandung so that it can produce products that are safe for consumption. The stages of the fish nugget production process start from the reception of raw materials, washing of raw materials, fish milling, mixing, division of dough, coating with flour coating, forming nugget dough, halfbaked frying, fish nugget, cooling and packaging. Based on the results of the identification there are 4 processes that become the critical control point (CCP), namely the receipt of raw materials, frying, cooling and packaging. To minimize potential hazards, critical control points for each CCP and monitoring system are established by specifying three elements for each CCP, namely the creation of procedures, documentation and the determination of the person responsible for each process that becomes the CCP. With the determination of this critical point, SMEs can make control of the process so that the resulting product has a good level of food security. This study also provides recommendations to SMEs to ensure that the application of HACCP can work well. Some recommendations are related to 5 aspects that have not met GMP requirements, namely building aspects, water security, maintenance and sanitation, materials and supervision programs.
\end{abstract}

Keyword: food safety, HACCP, fish nugget, SMES

\section{PENDAHULUAN}

Nugget merupakan salah satu produk olahan daging beku yang mempunyai daya simpan cukup lama dengan waktu penyimpanan dalam freezer bisa mencapai 2 minggu sampai 1 tahun. Daging yang digunakan harus digiling terlebih dahulu sehingga memudahkan untuk dibentuk 
pada tahapan berikutnya. Bahan utama yang digunakan adalah ikan, yang akan memberikan tekstur produk yang diinginkan, karena mempunyai kandungan protein myofibril.

Menurut BSN (2002) nugget merupakan produk olahan gilingan daging ayam yang dicetak, dimasak, dan dibekukan dengan penambahan bahan-bahan tertentu yang diizinkan. Perkembangannya, nugget telah dibuat dari beragam bahan bukan hanya ayam atau daging, namun dari bahan lain seperti ikan, sayuran, dan substitusi ayam atau daging dengan bahan-bahan lain seperti hati ayam (Yuliana et al. 2013), ubi jalar (Ekowati \& Cakrawati 2016), jamur tiram putih (Permadi et al. 2012), atau tepung ubi hutan (Ishak et al. 2014).

Nugget ikan merupakan produk siap saji yang dibuat dari daging giling dengan penambahan bumbu-bumbu dan bahan pengisi kemudian dilumuri dengan pelapis (coating dan breading) lalu dilakukan penggorengan (Aswar, 1995). Nugget ikan disukai oleh konsumen karena rasanya yang enak dan sifat penyajiannya praktis. Menurut SNI 7758:2013, nugget ikan yang baik memiliki kadar air maksimal $60 \%$, kadar lemak maksimal 15\%, kadar abu maksimal 2,5\% dan kadar protein minimal 5\% (BSN, 2013).

Ciri khas produk nugget ikan ini adalah memiliki tekstur yang elastis dan kenyal. Sifat elastis nugget ikan dipengaruhi oleh beberapa faktor, antara lain jenis ikan, tingkat kesegaran ikan, $\mathrm{pH}$ dan kadar air daging ikan, pencucian, umur ikan, suhu dan waktu pemanasan serta jenis dan konsentrasi zat tambahan. Mutu olahan nugget ikan yang baik adalah ketika tekstur nugget ikan yang dihasilkan adalah kenyal, rasa olahan nugget ikan tersebut gurih dan renyah karena adanya proses penambahan tepung roti yang memberikan kerenyahan produk, aromanya menunjukkan khas ikan serta berwarna kecoklatan setelah digoreng (Prihandini dkk, 2016).

Sebagai salah satu produk olahan ikan, nugget ikan merupakan makanan yang mengandung protein yang tinggi. Makanan tinggi protein rentan mengalami kerusakan dan merupakan kelompok makanan berisiko tinggi. Hal itu disebabkan karena nugget ikan memiliki derajat keasaman yang rendah. Produk pangan berasam rendah merupakan produk pangan yang mempunyai risiko tinggi bagi kesehatan karena produk pangan berasam rendah berpotensi bagi mikrobakteri untuk hidup dan berkembang biak (Amalia, 2012).

Industri atau usaha pembuatan nugget saat ini sangat berkembang pesat. Hal ini karena proses pembuatannya yang sederhana dan bahan baku yang mudah didapatkan. Industri pembuatan nugget ini banyak dilakukan oleh usaha kecil menengah. Berdasarkan survei lapangan yang dilakukan terhadap salah satu
UKM nugget ikan di Bandung terlihat bahwa UKM tersebut belum menerapkan prinsip keamanan pangan. Selain itu, pengawasan mutu yang dilakukan juga belum maksimal, sehingga mutu yang dihasilkan belum konsisten dan tidak memenuhi syarat mutu nugget ikan.

Produksi pangan yang aman dikonsumsi perlu menggunakan standar keamanan pangan (BSN, 1998). Salah satu standar keamanan pangan yang diakui adalah Hazard Analysis and Critical Control Point (HACCP). HACCP merupakan suatu piranti (sistem) yang digunakan untuk menilai bahaya dan menetapkan sistem pengendalian yang memfokuskan pada pencegahan. HACCP diterapkan pada seluruh mata rantai proses pengolahan produk pangan (Thaheer, 2005).

Program persyaratan dasar merupakan cara produksi makanan yang baik (Good Manufacturing Practice, GMP) atau praktik higiene yang baik (Good Hygiene Practice, GHP) yang akan dipatuhi oleh semua pelaku bisnis makanan, yang memiliki reputasi baik untuk memastikan bahwa makanan yang diberikan pada konsumen adalah makanan yang sehat dan aman (Prasetyo, 2000). Sistem manajemen mutu berfungsi sebagai kerangka acuan yang didalamnya setiap kegiatan proses dapat dikelola, termasuk sistem HACCP (Nurmawati, 2012). Maka dari itu, untuk meningkatkan keamanan pangan pada proses pembuatan nugget ikan ini diperlukan pengamatan dan penerapan HACCP. Pengamatan dan penerapan ini diharapkan mampu mengidentifikasi, menganalisis serta mengendalikan bahaya yang mungkin terjadi pada proses pembuatan nugget ikan. Berdasarkan data tersebut, penulis melakukan penelitian untuk mengembangkan sistem HACCP nugget ikan pada salah satu UKM di Bandung. Pemilihan UKM ini karena sudah memiliki jangkauan distribusi produk yang luas.

\section{TINJAUAN PUSTAKA}

HACCP adalah sistem pencegahan yang mengidentifikasi, mengukur, dan mengendalikan tingkat bahaya dalam sistem pangan, dengan tujuan memenuhi persyaratan keamanan pangan di perusahaan. Dalam prakteknya, HACCP melengkapi penerapan ISO 9000, sistem manajemen mutu, dan bahkan berfungsi sebagai dasar ISO 22000, sertifikasi manajemen keamanan pangan (Codex Alimentarius Commission 1-1969, Rev.3 1997). Ada 4 langkah kunci dalam menyiapkan dan menerapkan HACCP dalam sebuah perusahaan (Mortimore dan Wallace, 1998).

a. Perencanaan, yang mencakup analisis kesenjangan antara kondisi yang ada dengan prinsip dan persyaratan dasar HACCP; 
b. Melakukan, di mana perusahaan menerapkan 12 fase implementasi HACCP;

c. Memeriksa, atau rencana HACCP verifikasi sebelum implementasi penuh;

d. Bertindak, ketika rencana HACCP, program prasyarat, dan program manajemen keamanan pangan lainnya telah dilaksanakan dan dipantau.

Ada 12 langkah penerapan HACCP sesuai SNI 01-4852-1998. Dari langkah-langkah tersebut, lima tahap persiapan dan tujuh tahap merupakan prinsip HACCP seperti yang dijelaskan oleh Thaheer (2005) tercantum dalam Tabel 1. Secara teoritis ada tujuh prinsip dasar penting dalam penerapan sistem HACCP pada industri pangan seperti yang direkomendasikan baik oleh NACMCP (National Advisory Committee on Microbilogical Criteria for Foods) dan CAC (Codex Alintarius Commission). Ketujuh prinsip dasar penting HACCP yang merupakan dasar filosofi HACCP tersebut adalah:

Tabel 1 Tahapan HACCP.

\begin{tabular}{clcl}
\hline \multicolumn{1}{c}{ Persiapan HACCP } & \multicolumn{1}{c}{ Prinsip HACCP } \\
\hline Tahap & \multicolumn{1}{c}{ Program } & Tahap & \multicolumn{1}{c}{ Program } \\
\hline 1 & Pembentukan tim keamanan pangan & 6 & Analisis bahaya \\
2 & Penetapan karakteristik produk & 7 & Penetapan titik kendali kritis (CCP) \\
3 & Identifikasi tujuan penggunaan & 8 & Penetapan batas kritis tiap CCP \\
4 & Pembuatan diagram alir proses & 9 & $\begin{array}{l}\text { Penyusunan prosedur pemantauan tiap } \\
\end{array}$ \\
& Verifikasi diagram alir di lapangan & 10 & CCP \\
& & 11 & Penetapan tindakan koreksi \\
& & 12 & Penyusunan dokumentasi dan prosedur \\
& & &
\end{tabular}

Sumber : Thaheer (2005).

Prinsip I. Analisis bahaya (hazard Analysis) dan penetapan risiko beserta cara pencegahannya. Pendekatan pertama pada konsep HACCP adalah analisis bahaya yang berkaitan dengan semua aspek produk yang sedang diproduksi. Pemeriksaan atau analisis terhadap bahaya ini harus dilaksanakan, sebagai tahap utama untuk mengidentifikasi semua bahaya yang dapat terjadi bila produk pangan dikonsumsi. Analisis bahaya harus dilaksanakan menyeluruh dan realistis, dari bahan baku hingga ke tangan konsumen. Pada tahap analisis bahaya perlu adanya identifikasi bahaya yang spesifik di setiap alur proses, menentukan tingkat keparahannya (severity), menentukan tingkat probabilitasnya, menentukan tingkat risiko dan signifikansi bahayanya serta menentukan tindakan pengendalian bila bahayanya signifikan.

Jenis bahaya yang mungkin terdapat $d i$ dalam makanan dibedakan atas tiga kelompok bahaya, yaitu:

\section{a. Bahaya Biologis/Mikrobiologis}

Disebabkan oleh bakteri pathogen, virus atau parasit yang dapat menyebabkan keracunan, penyakit infeksi atau infestasi, seperti Escherichia coli, Listeria monocytogenes, Bacillus sp., Clostridium sp., virus Hepatitis A, dan lain;

\section{b. Bahaya Kimia}

Disebabkan oleh terpapar bahan kimia yang beracun, seperti aflatoksin, histamin, toksin jamur, toksin kerang, alkoloid pirolizidin, pestisida, antibiotika, hormon pertumbuhan, logam berat $(\mathrm{Pb}, \mathrm{Zn}, \mathrm{Ag}, \mathrm{Hg}$, sianida), bahan pengawet (nitrit, sulfit), pewarna (amaranth, rhodamin B, methanyl yellow), lubrikan, sanitizer, dan sebagainya.

\section{c. Bahaya Fisik}

Disebabkan oleh benda asing yang seharusnya tidak boleh terdapat di dalam makanan, seperti pecahan gelas, potongan kayu, kerikil, logam, serangga, potongan tulang, plastik, bagian tubuh (rambut), sisik, duri, kulit dan lain-lain. Agar analisis bahaya ini dapat benar-benar mencapai hasil yang dapat menjamin semua informasi mengenai bahaya dapat diperoleh, maka analisis bahaya harus dilaksanakan secara sistematik dan terorganisasi.

Ada tiga elemen dalam analisis bahaya, yaitu: 1) menyusun Tim HACCP, 2) mendefinisikan produk: cara produk dikonsumsi dan sifat negatif produk yang harus dikontrol dan dikendalikan, dan 3) identifikasi bahaya pada titik kendali kritis dengan mempersiapkan diagram alir proses yang teliti sesuai dengan keadaan yang sebenarnya, untuk menghasilkan suatu produk.

Prinsip II. Identifikasi dan penentuan titik kendali kritis (Critical Control Point/CCP) di dalam proses produksi titik kendali kritis (CCP) didefinisikan sebagai suatu titik lokasi, setiap langkah/tahap dalam proses, atau prosedur, apabila tidak terkendali dengan baik, berpotensi dapat menimbulkan tidak amannya makanan, kerusakan (spoilage), dan resiko kerugian ekonomi. CCP ini ditentukan setelah diagram alir proses produksi yang sudah teridentifikasi potensi bahaya pada setiap tahap produksi ataupun dapat langsung ditetapkan bila ada permintaan 
khusus dari pelanggan tanpa melalui decision tree. Secara sistematis untuk mengidentifikasi dan mengenali setiap titik kendali kritis (CCP) dapat dilakukan dengan metode alur keputusan atau CCP Decission Tree seperti terlihat pada Gambar 1.

Prinsip III. Penetapan batas kritis (Critical Limits) terhadap setiap CCP yang telah teridentifikasi. Setelah semua CCP dan parameter pengendali yang berkaitan dengan setiap CCP teridentifikasi, Tim HACCP harus menetapkan batas kritis untuk setiap CCP. Batas kritis untuk bahaya biologis/mikrobiologis, kimia dan fisika untuk setiap jenis produk berbeda satu sama lainnya. Batas kritis didefinisikan sebagai batas toleransi yang dapat diterima untuk mengamankan bahaya, sehingga titik kendali dapat mengendalikan bahaya kesehatan secara cermat dan efektif.

Batas kritis yang sudah ditetapkan ini tidak boleh dilanggar atau dilampaui, karena bila suatu nilai batas kritis yang dilanggar dan kemudian titik kendali kritisnya lepas dari kendali, maka dapat menyebabkan terjadinya bahaya terhadap kesehatan konsumen. Contoh batas kritis yang perlu ditetapkan sebagai alat pencegah timbulnya bahaya, seperti suhu dan waktu maksimal untuk proses thermal, suhu maksimal untuk menjaga kondisi pendinginan, suhu dan waktu tertentu untuk proses sterilisasi komersial, jumlah residu pestisida yang diperkenankan ada dalam bahan pangan., $\mathrm{pH}$ maksimal yang diperkenankan, bobot pengisian maksimal, viskositas maksimal yang diperkenankan dan sebagainya. Selain batas kritis untuk residu pestisida yang berasal dari komoditas pertanian, batas kritis bahan kimia lain yang berpotensi sebagai bahaya kimia juga harus ditetapkan.

Tim HACCP harus menggunakan peraturan yang sudah ditetapkan sebagai panduan dalam menetapkan batas kritis untuk semua bahan tambahan makanan termasuk bahan kimia yang digunakan dalam bahan pengemas yang bersentuhan dengan produk pangan. Batas kritis untuk setiap CCP perlu didokumentasikan. Dokumentasi ini harus dapat menjelaskan bagaimana setiap batas kritis dapat diterima dan harus disimpan sebagai bagian dari rencana formal HACCP. Batas kritis harus divalidasi untuk membuktikan bahaya yang diidentifikasi dapat dikendalikan. Operator CCP juga harus terlatih dan terbukti mampu mengendalikan CCP.

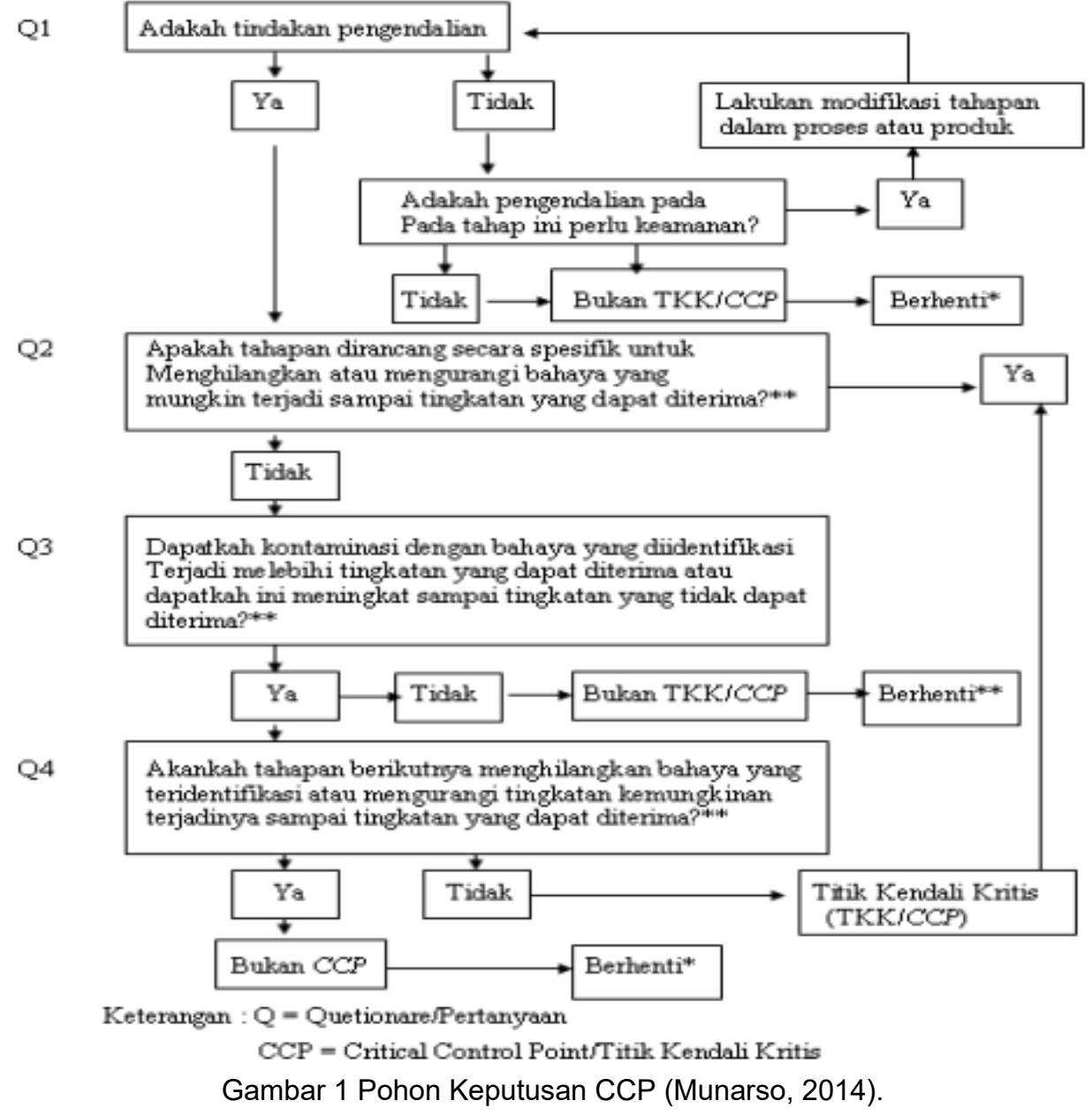


Cara dan prosedur monitoring untuk setiap CCP perlu diidentifikasi agar dapat memberi jaminan bahwa proses pengendalian pengolahan produk pangan masih dalam batas kritis dan dijamin keamanannya. Dalam hal ini, metode, prosedur dan frekuensi monitoring serta kemampuan hitungnya harus dibuat daftarnya pada lembaran kerja HACCP. Prosedur dan metode monitoring harus efektif dalam memberi jaminan keamanan terhadap produk pangan yang dihasilkan. Idealnya, monitoring pada CCP dilakukan secara kontinyu hingga dicapai tingkat kepercayaan $100 \%$. Namun bila hal ini tidak memungkinkan, dapat dilakukan monitoring secara tidak kontinyu dengan syarat terlebih dahulu harus ditetapkan interval waktu yang sesuai sehingga keamanan pangan benar-benar terjamin.

Biasanya agar pengukurannya dapat dilakukan secara cepat dan tepat, monitoring dilakukan dengan cara pengujian yang bersifat otomatis dan tidak memerlukan waktu yang lama. Oleh karena itu, pengujian dengan cara analisis mikrobiologis jarang digunakan sebagai prosedur monitoring. Contoh pengukuran dalam pemantauan (monitoring) adalah observasi secara visual dan pengamatan langsung seperti kebersihan lingkungan pengolahan, penyimpanan bahan mentah, pengukuran suhu dan waktu proses, $\mathrm{pH}$ dan kadar air.

Prinsip V. Melaksanakan tindakan koreksi yang harus dilakukan bila terjadi penyimpangan (deviasi) pada batas kritis yang telah ditetapkan. Meskipun sistem HACCP sudah dirancang untuk dapat mengenali kemungkinan adanya bahaya yang berhubungan dengan kesehatan dan untuk membangun strategi pencegahan preventif terhadap bahaya, tetapi masih terjadi penyimpangan yang tidak diharapkan. Oleh karena itu, jika dari hasil pemantauan (monitoring) ternyata menunjukkan telah terjadi penyimpangan terhadap CCP dan batas kritisnya, maka harus dilakukan tindakan koreksi (corrective action) atau perbaikan dari penyimpangan tersebut. Tindakan koreksi ini meliputi penanganan pada produk yang sedang diolah dan prosesnya termasuk metode dan peralatan yang digunakan.

Prinsip VI. membuat Prosedur Pencatatan dan Penyimpanan Data yang Efektif dalam Sistem Dokumentasi HACCP. Sistem doumentasi dalam sistem HACCP bertujuan untuk 1) mengarsipkan rancangan program HACCP dengan cara menyusun catatan yang teliti dan rapih mengenai seluruh sistem dan penerapan HACCP, 2) memudahkan pemeriksaan oleh manajer atau instansi berwenang jika produk yang dihasilkan diketahui atau diduga sebagai penyebab kasus keracunan makanan. Dalam melakukan pencatatan, beberapa hal yang dianjurkan adalah catatan harus sistematis, rapih dan teratur. Disamping itu, bila pencatatan dan pendokumentasian dilakukan tepat dan sesuai dengan sistem HACCP, maka berarti keefektifan sistem dokumentasi HACCP dapat diuji atau dibuktikan.

Prinsip VII. Membuat prosedur untuk memverifikasi bahwa sistem HACCP bekerja dengan benar. Prosedur verifikasi dibuat dengan tujuan: 1) untuk memeriksa apakah program HACCP telah dilaksanakan sesuai dengan rancangan HACCP yang ditetapkan dan 2) untuk menjamin bahwa rancangan HACCP yang ditetapkan masih efektif dan benar. Hasil verifikasi ini dapat pula digunakan sebagai informasi tambahan dalam memberikan jaminan bahwa program HACCP telah terlaksana dengan baik.

\section{METODE PENELITIAN}

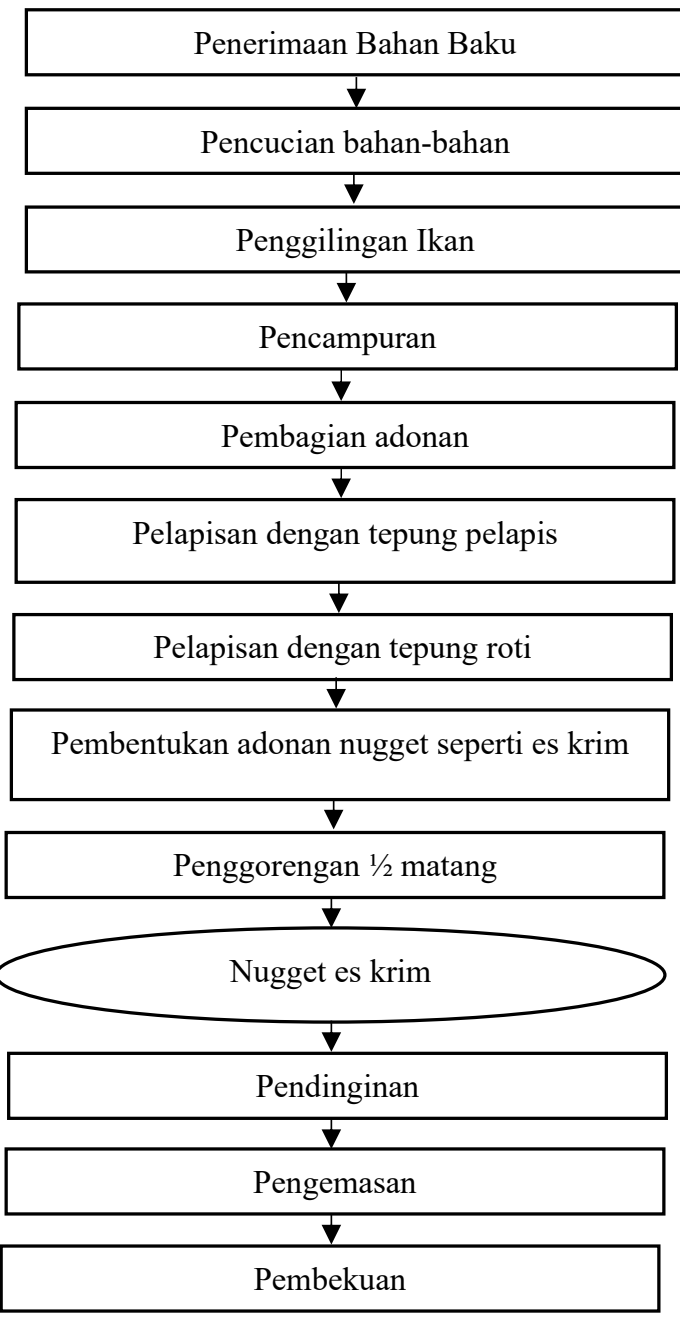

Gambar 2 Alur produksi Nugget Ikan (Hasil olah data Tahun 2018). 
Metodologi penelitian ini sesuai dengan prinsip HACCP yang terdapat pada SNI 01-48521998 tentang Sistem Analisa Bahaya dan Pengendalian Titik Kritis (HACCP) serta Pedoman Penerapannya. Tahap pertama dalam penelitian ini adalah studi pendahuluan untuk mengidentifikasi bahaya yang terkait selama proses pembuatan nugget ikan. Tahap kedua yang dilakukan yaitu penerapan prinsip HACCP mulai dari penentuan analisis bahaya, penentuan titik pengendalian kritis (Critical Control Point), penentuan batas kritis, pembuatan sistem monitoring CCP, melakukan tindakan korektif, penetapan prosedur verifikasi dan melakukan dokumentasi terhadap seluruh prosedur dan catatan. Tahap ketiga, rekomendasi dari analisis kesenjangan dan rencana implementasi HACCP (BSN, 1998).

\section{HASIL DAN PEMBAHASAN}

Data yang dikumpulkan terdiri dari data identifikasi konsumen dan diagram alur produksi dari produk. Selanjutnya, diagram alir divalidasi langsung dengan pengamatan di lapangan. Diagram alir produksi nugget ikan disajikan pada Gambar 2.

\section{a. Desain Sistem Manajemen Keamanan HACCP}

Titik kontrol kritis (CCP) ditentukan berdasarkan diagram alur proses dan analisis bahaya. Penelitian ini mengidentifikasi 4 CCP, yaitu pada proses penerimaan bahan baku, penggorengan, pendinginan dan pengemasan. Untuk meminimalkan potensi bahaya dibuat titik kendali kritis untuk masing-masing CCP dan sistem pemantauan dengan menetapkan tiga unsur untuk tiap CCP yaitu pembuatan prosedur, dokumentasi dan penetapan orang yang bertanggung jawab pada masing-masing proses yang menjadi CCP. Setelah itu, seluruh rencana diverifikasi menggunakan sampling, audit, dan verifikasi dokumen.

Proses penggorengan nugget ikan yang mendekati kriteria produk komersial, nugget

Tabel 2 Rekomendasi perbaikan pada aspek GMP.

\begin{tabular}{ll}
\hline \multicolumn{1}{c}{ Aspek } & \multicolumn{1}{c}{ Rekomendasi } \\
\hline Bangunan & Pengendalian hama oleh jasa pest control \\
Keamanan air & Melaporkan hasil pengawasan program pest control \\
& ke bagian sanitasi \\
& Prosedur pembersihan tangki air secara berkala \\
Pemeliharaan dan program sanitasi & Pengujian sampel air di laboratorium secara berkala \\
& Pemeriksaan visual air setiap hari \\
Bahan & Prosedur pembersihan alat dan mesin \\
Pengawasan & Prosedur kebersihan dan sanitasi karyawan \\
& Persyaratan mutu bahan baku \\
& Prosedur penyimpanan bahan baku \\
& Pemantauan kondisi kesehatan karyawan secara \\
\end{tabular}

Sumber : Hasil olah data tahun 2018. dapat digoreng selama 2 menit dalam suhu $180^{\circ} \mathrm{C}$. Kriteria produk komersial yaitu meliputi warna (merah kecokelatan), penampakan (utuh, rapi, permukaan rata, ketebalan utuh), tekstur (kenyal, kompak, padat) dan rasa (terasa ikan, gurih) (Erawaty, 2001). Sedangkan untuk proses pengemasan dan penyimpanan, sebaiknya produk nugget ikan tidak disimpan lebih dari 12 hari. Menurut Erawaty (2001) akan terjadi peningkatan kekerasan saat nugget ikan disimpan selama 12 hari.

Dokumen dan prosedur penyimpanan catatan harus didokumentasikan dengan baik. Proses dokumentasi ini bermanfaat bagi perusahaan untuk membuat analisis akar permasalahan berbasis data, pemantauan CCP dan penilaian kinerja untuk sertifikasi.

\section{b. Analisis Pemenuhan Program Prasyarat}

Tujuan dari program prasyarat adalah untuk menjamin kelangsungan proses produksi dan kesehatan lingkungan selama pelaksanaan HACCP. Penelitian ini menganalisis pemenuhan dua program prasyarat: Analisis Good Manufacturing Practices (GMP) dan Sanitation Standard Operational Procedure (SSOP). GMP adalah sistem yang memastikan setiap produk diproduksi dan dikendalikan sesuai dengan standar yang diperlukan. Analisis GMP didasarkan pada regulasi pengolahan makanan 75/M-IND/PER/7/2010 dari Kementerian Perindustrian Indonesia. Hasil analisis regulasi GMP, terdapat 5 aspek yang belum terpenuhi yaitu aspek bangunan, keamanan air, pemeliharaan dan program sanitasi, bahan serta pengawasan.

\section{c. Usulan Perbaikan dan Analisis Implikasi}

Berdasarkan analisis pada implementasi HACCP, pemenuhan program prasyarat, dan kondisi perusahaan yang ada, penelitian ini merekomendasikan beberapa perbaikan. Rekomendasi dibuat pada aspek GMP yang belum dapat dipenuhi oleh perusahaan. Rekomendasi perbaikan dijelaskan pada Tabel 2. Melaporkan hasil pengawasan program pest control

Pengujian sampel air di laboratorium secara berkala

Pemeriksaan visual air setiap hari

Prosedur pembersihan alat dan mesin

Persyaratan mutu bahan baku

Pemantauan kondisi kesehatan karyawan secara 
5.

\section{KESIMPULAN}

Sistem manajemen keselamatan berbasis HACCP dirancang pada produsen nugget ikan. Selanjutnya, ada tiga hasil utama yang disimpulkan oleh penelitian ini: rencana HACCP sebagai hasil utama dari penelitian ini, perancangan sistem dokumentasi untuk memperkuat implementasi, dan rekomendasi perbaikan pada aspek GMP untuk memastikan pelaksanaan HACCP yang efektif.

Output dari sistem manajemen keselamatan berbasis HACCP adalah rencana HACCP. Tujuan dari rencana ini adalah untuk menjaga kualitas dan keamanan pangan produk nugget ikan. Rencana terdiri dari 4 titik kontrol kritis (CCP), masing-masing dengan batas kritis, persyaratan pemantauan, tindakan korektif, verifikasi, dan prosedur dokumentasi.

Kedua, penelitian ini mengusulkan sistem dokumentasi yang bertujuan untuk mengontrol efektivitas implementasi HACCP. Untuk memenuhi aspek GMP dibuat 8 dokumen prosedur. Dokumen ini mengatur terkait personil, syarat mutu, dan tindakan yang perlu dilakukan jika terjadi ketidaksesuaian pada aspek GMP tersebut.

Ketiga, berdasarkan kondisi di lapangan pada UKM, ada beberapa usulan perbaikan pada aspek GMP yang direkomendasikan pada penelitian ini untuk memastikan penerapan HACCP dapat berjalan dengan efektif. Rekomendasi ini bertujuan untuk memperbaiki kondisi UKM terutama pada aspek bangunan, keamanan air, pemeliharaan dan program sanitasi, bahan serta proses pengawasan.

\section{UCAPAN TERIMA KASIH}

Penulis mengucapkan terima kasih kepada pimpinan Badan Standardisasi Nasional (BSN) yang telah mengalokasikan anggaran untuk penelitian ini. Ucapan terimakasih juga disampaikan kepada Ibu Novia Priyatna dan tim Puslitbang BSN yang telah memberikan pemikiran dalam penelitian ini.

\section{DAFTAR PUSTAKA}

Amalia, Ulfah. (2012). Pendugaan Umur Simpan Produk Nugget Ikan dengan
Merk Dagang Fish Nugget So Lite. Jurnal Saintek Perikanan. 8 (1)

Aswar. (1995). Pembuatan Fish Nugget dari Ikan Nila Merah (Oreochromis sp.). Skripsi. Teknologi Hasil Perikanan. Institut Pertanian Bogor, Bogor.

Badan Standardisasi Nasional (BSN). (1998). Sistem Analisa Bahaya dan Pengendalian Titik Kritis (HACCP) serta Pedoman Penerapannya. Standar Nasional Indonesia. SNI 01-4852-1998.

Badan Standarisasi Nasional (BSN). (2002). SNI 01-6883-2002 Nugget Ayam. Jakarta.

Badan Standarisasi Nasional (BSN). (2013). SNI 7758:2013 Nugget Ikan. Jakarta.

Ekowati BA, Cakrawati D. (2016). Modifikasi nugget ayam dengan penambahan pati resisten ubi jalar sebagai serat pangan. Fortech. 1(1): 53-58.

Erawaty, Widyah Retno. (2001). Pengaruh Bahan Pengikat, Waktu Penggorengan terhadap Sifat Fisik dan Organoleptik Produk Nugget Ikan Sapu-sapu. Skripi. IPB. Bogor.

Ishak M, Saleh EJ, Rachman AB. (2014). Karakteristik kadar protein, lemak, dan karbohidrat nugget ayam yang terbuat dari tepung ubi hutan (Dioscorea hispida dennst). IImiah Agrobisnis Tropis. 7(3): 120-124.

Mortimore, S. dan Wallace, C. (1998). HACCP a practical approach. Gaithersburg, Maryland USA. Aspen Publisher Inc.

Munarso, S. Joni dan Miskiyah. (2014). Penerapan Sistem HACCP (Hazard Analysis and Critical Control Points) pada Penanganan Pascapanen Kakao Rakyat. Jurnal Standardisasi Volume 16 Nomor 1, Maret 2014: Hal 17-30

Nurmawati. (2012). Proses Pembentukan Pola Perilaku Kerja Karyawan PT. Indopherin Jaya melalui Budaya Organisasi 5S (Studi Kasus pada Karyawan PT. Indopherin Jaya, Kota Probolinggo. Skripsi. Universitas Brawijaya. Malang

Permadi SN, Mulyani S, Hintono A. (2012). Kadar serat, sifat organoleptik, dan rendemen nugget ayam yang disubstitusi dengan jamur tiram putih (Plerotus ostreatus). Aplikasi Teknologi Pangan. 1(4): 115-120. 
Jurnal Standardisasi Volume 21 Nomor 1, Maret 2019: Hal 1 - 8

Jurnal Standardisasi Volume 21 Nomor 1, Maret 2019: Hal 1 - 8

